Review

\title{
Genotoxicity of ethylene oxide: A review of micronucleus assay results in human population
}

\author{
Manosij Ghosh $^{\mathrm{a}, *}$, Lode Godderis ${ }^{\mathrm{a}, \mathrm{b}, * *}$ \\ ${ }^{a}$ KULeuven, Department of Public Health and Primary Care, Centre Environment E' Health, B-3000 Leuven, Belgium \\ ${ }^{\mathrm{b}}$ Idewe, External Service for Prevention and Protection at Work, B-3001 Heverlee, Belgium
}

\section{A R T I C L E I N F O}

\section{Article history:}

Received 12 December 2015

Received in revised form 7 May 2016

Accepted 9 May 2016

Available online 20 May 2016

\section{Keywords:}

Ethylene oxide

Micronucleus assay

\begin{abstract}
A B S T R A C T
Ethylene oxide (EtO) has been categorized as "carcinogenic to humans (Group 1)" by the IARC. While several epidemiological studies have reported carcinogenicity and EtO-Hb formation; information from cytogenetic endpoints are rather inconclusive. In the present review, we focus on the results of eleven studies which have reported the results of micronucleus assay in EtO exposed workers. We have critically reviewed these studies based on the exposure assessment, concentration and duration, and compared the sensitivity of micronucleus assay to other reported endpoints like EtO-Hb, CA, SCE. The levels of EtO and EtO-Hb adducts in all the studies were strongly correlated to the results of SCE, but not to MN. MN were only observed in a limited number of studies with high EtO exposure (2-28 ppm $8 \mathrm{~h}$-TWA) and not below the recommended concentration of $<1 \mathrm{ppm}$. To further understand the effect of exposure of EtO on MN assay outcome, we propose studies with more harmonized protocol for exposure assessment and MN analysis, determination of suitable sample size and use of multiple target tissues to understand the effect of metabolite.
\end{abstract}

(c) 2016 Elsevier B.V. All rights reserved.

\section{Contents}

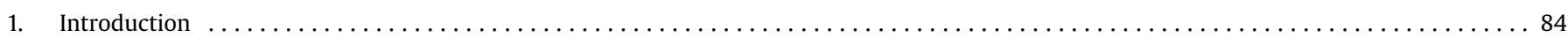

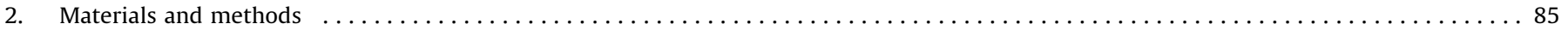

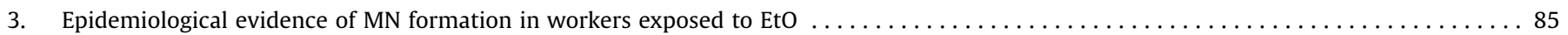

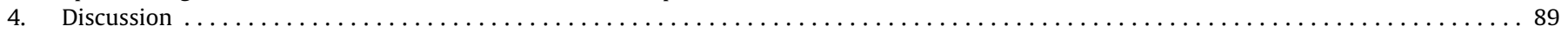

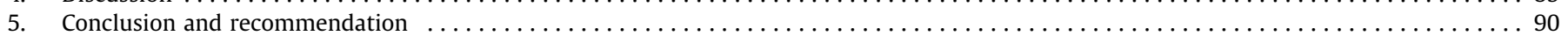

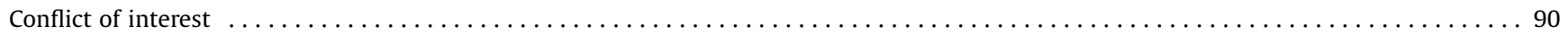

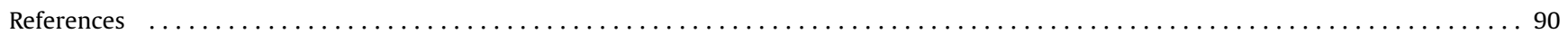

\section{Introduction}

Ethylene oxide (EtO) is a frequently produced organic chemical, used as an intermediate for production of several chemicals including ethylene glycol, ethoxylates among others. It is also

\footnotetext{
Abbreviations: EtO, ethylene oxide; EtO-Hb adduct, ethylene oxide-haemoglobin adduct; CA, chromosomal aberrations; MN, micronuclei; SCE, sister chromatid exchanges; 8-h TWA, $8 \mathrm{~h}$ time weighted average.

* Corresponding author.

** Corresponding author at: KULeuven, Department of Public Health and Primary Care, Centre Environment \& Health, B-3000 Leuven, Belgium.

E-mail addresses: gmanosij@gmail.com (M. Ghosh),

lode.godderis@med.kuleuven.be (L. Godderis).
}

commonly used in sterilization of medical instruments and devices. With an estimated global production of $\sim 20$ million tonnes, it is one of the most produced organic chemicals.

The high global production of EtO increases the risks of environmental and occupational exposure. The CAREX EU report published in 1999 estimated the number of workers exposed to EtO at 46900 [1]. According to the report, approximately 22300 workers were involved in medical, dental, other health services, while 1000 workers were involved in production of EtO. Reports from US National Occupational Exposure Survey between 1981 and 1983, estimated that approximately 270000 workers were exposed to varying concentrations of EtO [2], of which 98997 workers were associated with health services. More recent estimates of 
CAREX-Canada [3], suggests that approximately 2400 workers are exposed to EtO at workplace, of which more than 2100 were involved in the health care and sterilization services.

Comparison of historical data from various sources including CAREX EU [1], IARC [4-6], US National Occupational Exposure Survey [2], CAREX-Canada [3] clearly indicates that exposure to workers involved in sterilization process has been much higher (1$30 \mathrm{ppm})$, compared to exposure levels during EtO synthesis $(<1 \mathrm{ppm})$. Accidental exposure to EtO is common during and after the sterilizing cycles as well. These exposures are usually above the odour threshold of $500 \mathrm{ppm}$ and are extremely hazardous. Several other accounts of accidental exposure to EtO have been reported [7-10] and is usually between 300 and 700 ppm.

While, acute exposures are known to cause nausea, bronchitis, pulmonary oedema; workers with chronic exposure are at risk of developing neurological disorders and cancer [11,12]. EtO is also a known alkylating (hydroxyethylating) agent, which can lead to the formation of adducts with DNA [13,14] and proteins like haemoglobin [15,16]. Several cytogenetic studies, in vitro and in vivo, have confirmed the genotoxicity and mutagenicity of EtO. Studies have also provided substantial evidence of carcinogenicity in rodents. Over the years, several epidemiological studies have associated EtO exposure with cancers in human [17,18] including gastro-intestinal and breast cancers $[19,20]$.

Based on limited evidences of toxicity, EtO was first listed in the Fourth Annual Report on Carcinogens in 1985 "as possible human carcinogen". Considering the DNA-damaging activity of EtO and increased risk of cancer, demonstrated by epidemiological studies, the listing was revised to "known to be a human carcinogen" in the Ninth Report on Carcinogens in 2000 [21]. Similarly, EtO was considered by the IARC Working Groups from 1976 to 2012, and based on several evidences EtO has been categorized as "carcinogenic to humans (Group 1)".

Consequently, from an occupational perspective it is important to adequately follow-up workers exposed to EtO at regular intervals. Traditionally, the most common method for biomonitoring is the measurement of EtO metabolites (in urine) or EtO adducts (haemoglobin and DNA). Nevertheless, cytogenetic studies provide significant information regarding EtO toxicity. It also provides possible mechanistic explanation of carcinogenesis. In this review we discuss EtO toxicity with special emphasis on the micronucleus assay in human population. The results of micronucleus assay are critically reviewed, highlighting the exposure concentrations, study design, findings and the knowledge gaps. The results are also compared to various other genotoxicity assays, thus providing an overview regarding the sensitivity of micronucleus assay in EtO bio-monitoring. Finally, the findings are summarised, and some recommendations are put forward.

\section{Materials and methods}

Several epidemiological studies have considered different aspects of EtO toxicity, including carcinogenicity and mortality. While many studies have included exposure measurement and EtO haemoglobin adduct formation (EtO-Hb), only a limited number of studies have addressed the cytogenetic endpoints. A literature search was therefore performed till December 2015 using PubMed and Scopus databases. Search string of "ethylene oxide" [All Fields] and "Micronucleus" [All Fields] in Pubmed returned a total of 23 results. Search string "Title-Abs-Key (Ethylene Oxide) And TitleAbs-Key (Micronucleus)" for article published in journals returned a total of 37 results in Scopus search. These search results included articles reporting $\mathrm{MN}$ formation in animal models and a limited number of epidemiological evidences. A manual search of these references was subsequently performed. For the interest of the present review, 11 studies were selected based on their inclusion of micronucleus assay (MN) in human population as one of the test endpoints. Additionally, some of the evaluated studies also reported results of sister chromatid exchanges (SCE), chromosomal aberrations (CA), DNA single-strand breaks (SSB), HPRT mutations.

\section{Epidemiological evidence of $\mathrm{MN}$ formation in workers exposed to EtO}

The eleven shortlisted studies on workers exposed to ethylene oxide have been described in this section. The articles were analyzed with respect to their quality and the observations from these reports are critically reviewed below and summarised in Table 1, highlighting the study population, EtO exposure, levels of EtO-Haemoglobin adducts (EtO-Hb) and the methods and results of genotoxicity assays performed. For each study reported, frequency ratio ( $\mathrm{FR}=\mathrm{MN}$ in exposed population/MN in control) was calculated for micronucleus assay for convenience of comparison between different studies, and has been represented in Fig. 1. Additionally, a quality score was assigned to each of the study out maximum possible score of 27 (Supplementary Table 1).

Högstedt et al. [22] investigated the effect of EtO on different cytogenetic parameters in an exposed Swedish population. They studied a group of 28 workers exposed to EtO and 20 control subjects. The workplace exposure during biological sampling was less than $1 \mathrm{ppm}$ ( $8 \mathrm{~h}$-TWA), with occasional high exposure of up to $52 \mathrm{ppm}$. The workers of two factories and controls were studied for several cytogenetic parameters including SCE in lymphocyte cells, and $\mathrm{CA}$ and $\mathrm{MN}$ in lymphocyte and bone marrow cells. Workers exposed in both the factories had higher frequency of CA than controls in lymphocyte cells. The frequency of SCE in lymphocyte however remained unaltered in the exposed and control groups. MN in lymphocyte cells revealed no significant change (FR for Factory $1=1.16$; Factory 2: 0.75 ). A comparison between the cytogenetic endpoints indicated that CA was more sensitive in detecting genotoxic effects of EtO in both lymphocyte and bone marrow cells. The authors also suggested that bone marrow MN were good biomarker of EtO toxicity, however its use is limited by the difficulty of sampling.

In a later study, Högstedt et al. [23], compared the cytogenetic effects of EtO and propylene oxide exposure in a group of Swedish workers. A total number of 18 subjects (EtO exposed) were included, with mean age $30.8 \pm 8.1$. EtO-Hb adducts were measured and were between $1.2-10 \mathrm{nmol} / \mathrm{gHb}$ (mean- $3.3 \mathrm{nmol} /$ $\mathrm{gHb}$ ). The authors studied a total of 100 metaphase spreads to study CA. The percentage of CA in the study population was five. MN assay was performed according to the method of Hogstedt [24]. Briefly, lymphocyte cells were harvested after $72 \mathrm{~h}$ of culture, smear prepared and stained with May-Grunwald-Giemsa's stain. A total of 1000 cells were scored. MN frequency in the EtO exposed workers were reported to be $5.78 \%$. A dose response study among the workers based on their EtO-Hb levels and MN frequency did not reveal significant correlation. However, since the study lacks a well-defined control population, it is extremely difficult to interpret the results of EtO exposure.

To understand the biological effect of EtO, Mayer et al. [25] evaluated a number of endpoints including EtO-Hb, SCEs, MN, CA, SSB and index of DNA repair. The study was conducted with 34 (10 male; 24 female) workers exposed to EtO and 24 control subjects. Workers were exposed to an EtO concentration of $0.1 \mathrm{ppm}$, while control population were exposed to much lower levels (below $0.02 \mathrm{ppm}$ ). Workplace exposure to EtO significantly increased SCE, and affected DNA repair capacity. The results SCE and DNA repair assay were strongly correlated with that of EtO-Hb levels. However CA, SSB were not affected by the workplace exposure to EtO, or smoking habits. MN formation remained unaltered amongst 
Table 1

Summary of epidemiological studies investigating genetic damage in human population exposed to EtO.

\begin{tabular}{|c|c|c|c|c|c|c|c|c|c|}
\hline $\begin{array}{l}\text { Exposure subjects, } \\
\text { country }\end{array}$ & $\begin{array}{l}\text { Year (study } \\
\text { conducted/ } \\
\text { published) }\end{array}$ & Number of participants (age) & EtO exposure & EtO-Hb & Markers of genotoxicity & $\begin{array}{l}\text { Results and } \\
\text { comments }\end{array}$ & $\mathrm{FR}^{\wedge}$ & QS & Ref. \\
\hline $\begin{array}{l}\text { Sterilization of } \\
\text { equipment, } \\
\text { Sweden }\end{array}$ & 1983 & $\begin{array}{l}\text { E: } \mathbf{2 8} \\
\text { Factory } \mathbf{1}^{\text {t}}: 1 \mathrm{~m}+17 \mathrm{f}(37) \\
\text { Factory } \mathbf{2}^{\mathrm{t}}: 10 \mathrm{~m}(36) \\
\text { C: } \\
\text { Control IA }{ }^{\mathrm{t}}: 11 \mathrm{f}(44) \\
\text { Control IB }^{\text {t: }}: 8 \mathrm{~m}+2 \mathrm{f} \\
\text { Control II }^{\text {t: }}: 9 \mathrm{~m}(29) \\
{ }^{\mathrm{t}} \text { Groups as defined by authors }\end{array}$ & $\begin{array}{l}8 \mathrm{~h}-\mathrm{TWA}<1 \mathrm{ppm} ; \\
\text { momentary peak levels } \\
52 \mathrm{ppm}\end{array}$ & NR & $\begin{array}{l}\text { MN-lymphocyte } \\
\text { MN in mononuclear cells, } 2000 \\
\text { cells scored } \\
\text { MN-bone marrow cells } \\
\text { MN in } 1000 \text { PCE and } \\
\text { erythroblast respectively } \\
\text { CA-lymphocyte and bone } \\
\text { marrow) } \\
\text { SCE-lymphocyte }\end{array}$ & $\begin{array}{l}\text { MN-lymphocyte - } \\
\leftrightarrow \\
\text { MN-bone marrow- } \\
\uparrow^{*} \\
\text { CA- } \uparrow^{*} \\
\text { SCE- } \leftrightarrow\end{array}$ & $\begin{array}{l}\text { Factory 1-1.16 } \\
\text { Factory 2: } 0.75\end{array}$ & $14 / 27$ & $\begin{array}{l}\text { Högstedt } \\
\text { et al. [22] }\end{array}$ \\
\hline $\begin{array}{l}\text { Sterilizers and } \\
\text { assemblers; } \\
\text { Sweden }\end{array}$ & 1990 & E: $18(30.8 \pm 8.1)$ & $\begin{array}{l}8 \mathrm{~h} \text {-TWA } \\
2 \mathrm{ppm}\end{array}$ & $\begin{array}{l}1.2-10 \mathrm{nmol} / \mathrm{g} \mathrm{Hb} \\
(\text { mean- } 3.3 \mathrm{nmol} / \mathrm{g} \\
\mathrm{Hb})\end{array}$ & $\begin{array}{l}\text { MN- MN in mononuclear cells, } \\
1000 \text { cells scored } \\
\text { CA- lymphocyte }\end{array}$ & $\begin{array}{l}\text { MN-lymphocyte - } \\
5.78 \% \\
\text { CA- } 5 \%\end{array}$ & $\begin{array}{l}\text { Well defined } \\
\text { control } \\
\text { population } \\
\text { absent }\end{array}$ & $11 / 27$ & $\begin{array}{l}\text { Högstedt } \\
\text { et al. [23] }\end{array}$ \\
\hline $\begin{array}{l}\text { Central Sterile Supply } \\
\text { workers; New York, } \\
\text { U.S.A. }\end{array}$ & 1988 & $\begin{array}{l}\text { E: } 10 m+24 f(36.70 \pm 10.50) \\
\text { C: } 7 m+16 f(46.30 \pm 13.30)\end{array}$ & $\begin{array}{l}8 \mathrm{~h}-\mathrm{TWA} \\
0.3-0.5 \mathrm{ppm}\end{array}$ & $\begin{array}{l}\text { E: } 170 \pm 17 \mu \mathrm{mol} / \\
\text { mol Hb } \\
\text { C: } 66 \pm 12 \mu \mathrm{mol} / \\
\text { mol Hb }\end{array}$ & $\begin{array}{l}\text { MN- MN in mononuclear cells, } \\
1000 \text { cells scored } \\
\text { CA- lymphocyte } \\
\text { SCE- lymphocyte }\end{array}$ & $\begin{array}{l}\text { MN-lymphocyte - } \\
\overleftrightarrow{\leftrightarrow} \\
\text { CA- } \leftrightarrow \\
\text { SCE- } \uparrow^{*}\end{array}$ & 0.95 & $16 / 27$ & $\begin{array}{l}\text { Mayer } \\
\text { et al. [25] }\end{array}$ \\
\hline $\begin{array}{l}\text { Sterilization of } \\
\text { medical equipment }\end{array}$ & 1991 & $\begin{array}{l}\text { E: } 10(40.4) \\
\text { C: } 10(39)\end{array}$ & $\begin{array}{l}6.5 \mathrm{~h}-\mathrm{TWA} \\
0.025-0.38 \mathrm{ppm}\end{array}$ & $\begin{array}{l}\text { E: } 78-430 \text { pmol/ } \\
\text { mg Hb } \\
\text { C: } 21-88 \text { pmole/ } \\
\text { mg Hb }\end{array}$ & $\begin{array}{l}\text { MN-lymphocyte- MN scored in } \\
1800 \text { binucleated cells } \\
\text { MN-Buccal cells MN in } \\
\text { mononuclear cells, } 3000 \text { cells } \\
\text { scored } \\
\text { CA- lymphocyte } \\
\text { SCE- lymphocyte }\end{array}$ & $\begin{array}{l}\text { MN-lymphocyte- } \\
\stackrel{\leftrightarrow}{\text { MN-Buccal cells- }} \\
\stackrel{\leftrightarrow}{\text { SCE- } \leftrightarrow}\end{array}$ & 1.18 & $14 / 27$ & $\begin{array}{l}\text { Sarto et al. } \\
\text { [26] }\end{array}$ \\
\hline $\begin{array}{l}\text { Operators of hospital } \\
\text { sterilizers; USA and } \\
\text { Mexico }\end{array}$ & 1992 & $\begin{array}{l}\text { E: } 73 ; 96 \% \mathrm{f} \\
(38.32 \pm 8.5 ; \text { American } \\
\text { participants } 13 \text { years older than } \\
\text { Mexican participants })\end{array}$ & $\begin{array}{l}8 \mathrm{~h}-T W A \\
\text { USA- } 0.04-0.16 \mathrm{ppm} \\
\text { Mexico- } 0.02-0.54 \mathrm{ppm}\end{array}$ & $\begin{array}{l}\text { E: } 0.06- \\
0.16 \mathrm{pmol} / \mathrm{mg} \mathrm{Hb}\end{array}$ & $\begin{array}{l}\text { MN- lymphocytes harvested } \\
\text { at } 84 \text { and } 96 \mathrm{~h} \text { after initiation, } \\
\text { MN in mononuclear cells, } 1000 \\
\text { cells scored } \\
\text { SCE- lymphocyte }\end{array}$ & $\begin{array}{l}\text { MN-lymphocyte - } \\
\leftrightarrow \\
\text { SCE- } \leftrightarrow \text { in Mexico } \\
\uparrow^{*} \text { USA } \\
\text { Positive association } \\
\text { between EtO-Hb } \\
\text { and SCE }\end{array}$ & $\begin{array}{l}\text { USA- } 1.5 \\
\text { Mexico- } 1.12\end{array}$ & $15 / 27$ & $\begin{array}{l}\text { Schulte } \\
\text { et al. [27] }\end{array}$ \\
\hline $\begin{array}{l}\text { Sterilization of } \\
\text { medical } \\
\text { equipment; } \\
\text { Germany }\end{array}$ & 1991 & 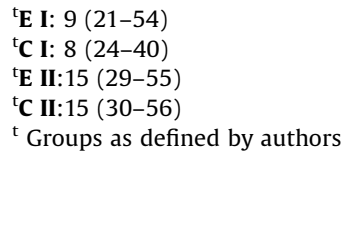 & $\begin{array}{l}\text { E I: } 22-72 \mathrm{ppm} \\
\text { 8-h TWA of } 0.13 \mathrm{ppm} \\
\text { E II: } 14-28 \mathrm{ppm} \text {; peak } \\
\text { around } 400 \mathrm{ppm} \\
8 \mathrm{~h}-\mathrm{TWA} \\
\text { of } 5 \mathrm{ppm}\end{array}$ & $\begin{array}{l}\text { E I: } 0.179 \mathrm{nmol} / \mathrm{g} \\
\mathrm{Hb} \\
\text { C I: } 0.066 \mathrm{pmol} / \mathrm{g} \\
\mathrm{Hb} \\
\text { E II: } 7.70 \mathrm{pmol} / \mathrm{rng} \\
\mathrm{Hb} \\
\text { C II: } 0.102 \mathrm{pmol} / \mathrm{g} \\
\mathrm{Hb}\end{array}$ & $\begin{array}{l}\text { MN- MN were scored in } 1000 \\
\text { binucleated cells } \\
\text { CA- lymphocyte } \\
\text { SCE- lymphocyte } \\
\text { HPRT mutation }\end{array}$ & $\begin{array}{l}\text { MN-lymphocyte - } \\
\leftrightarrow \text { in E I } \\
\uparrow \text { in E II } \\
\text { CA- } \uparrow^{*} \text { in EI and E II } \\
\text { SCE- } \uparrow^{*} \text { in EI and E II } \\
\text { HPRT mutation- } \\
\uparrow^{*} \text { in E II } \\
\leftrightarrow \text { in E I }\end{array}$ & $\begin{array}{l}\text { EI:CI- } 1.06 \\
\text { EII:CII- 1.70 }\end{array}$ & $18 / 27$ & $\begin{array}{l}\text { Tates et al. } \\
{[28]}\end{array}$ \\
\hline
\end{tabular}




\begin{tabular}{|c|c|c|c|c|c|c|c|c|c|}
\hline $\begin{array}{l}\text { Industry workers; } \\
\text { The Netherlands }\end{array}$ & 1995 & $\begin{array}{l}\text { Exposed } \\
\text { EI }^{\mathbf{t}}: 7(37 \pm 13) \\
\text { EII }^{\mathbf{t}}: 7(31 \pm 5) \\
\text { EIII }^{\mathbf{t}}: 7(47 \pm 6) \\
\text { Control } \\
\text { EIV }^{\mathbf{t}}: 7(44 \pm 8)\end{array}$ & $\begin{array}{l}\text { EI:incidentally exposed } \\
\text { to acute high doses of } 28- \\
436 \mathrm{ppm} \\
\text { EII: exposed to }<0.01 \text { for } \\
\text { less than } 5 \text { years } \\
\text { EIII: exposed to }<0.01 \text { for } \\
\text { more than } 15 \text { years } \\
\text { EIV:unexposed }\end{array}$ & $\begin{array}{l}\text { EI: } 35- \\
4902 \mathrm{pmol} / \mathrm{g} \mathrm{Hb} \\
\text { EII: } 0-75 \mathrm{pmol} / \mathrm{g} \\
\mathrm{Hb} \\
\text { EIII: } 0-43 \mathrm{pmol} / \mathrm{g} \\
\mathrm{Hb} \\
\mathrm{EIV}: 0-32 \mathrm{pmol} / \mathrm{g} \\
\mathrm{Hb} \\
\text { Values of March/ } \\
\text { May 1993 } \\
\text { reported here }\end{array}$ & $\begin{array}{l}\text { MN- MN were scored in 1000/ } \\
1500 \text { binucleated cells } \\
\text { CA- lymphocyte } \\
\text { SCE- lymphocyte } \\
\text { HPRT mutation }\end{array}$ & $\begin{array}{l}\text { MN-lymphocyte - } \\
\leftrightarrow \\
\text { SCE- } \leftrightarrow \\
\text { HPRT mutation- } \leftrightarrow\end{array}$ & $\begin{array}{l}\text { EI:EIV- } 0.89 \\
\text { EII:EIV- } 1.14 \\
\text { EIII:EIV- } 0.93\end{array}$ & $17 / 27$ & $\begin{array}{l}\text { Tates et al. } \\
{[30]}\end{array}$ \\
\hline $\begin{array}{l}\text { Industry workers; } \\
\text { Brazil }\end{array}$ & 1994 & $\begin{array}{l}\text { E: } 75 \mathrm{~m} \\
\text { C: } 22 \mathrm{~m}\end{array}$ & $\begin{array}{l}8 \mathrm{~h}-\mathrm{TWA} \\
2-5 \mathrm{ppm}\end{array}$ & $\begin{array}{l}\text { E: } 294 \pm 121 \mathrm{nmol} / \\
\text { g Hb } \\
\text { C: } 92 \pm 78 \mathrm{nmol} / \mathrm{g} \\
\mathrm{Hb}\end{array}$ & $\begin{array}{l}\text { MN-lymphocyte- MN scored in } \\
1000 \text { binucleated cells } \\
\text { MN-Buccal cells MN in } \\
\text { mononuclear cells, } 1000 \text { cells } \\
\text { scored } \\
\text { CA- lymphocyte } \\
\text { SCE- lymphocyte }\end{array}$ & $\begin{array}{l}\text { MN-lymphocyte- } \\
\uparrow^{*} \\
\text { MN-Buccal cells } \\
-\leftrightarrow \\
\text { CA- } \uparrow^{*}\end{array}$ & 3.63 & $15 / 27$ & $\begin{array}{l}\text { Ribeiro } \\
\text { et al. [31] }\end{array}$ \\
\hline $\begin{array}{l}\text { Hospital workers, } \\
\text { Croatia }\end{array}$ & 1999 & $\begin{array}{l}\text { E: } 11 \mathrm{f} \\
\text { C: } 20 \mathrm{f}\end{array}$ & $2 \mathrm{ppm}$ & NR & $\begin{array}{l}\text { MN-lymphocyte- MN scored in } \\
1000 \text { binucleated cells } \\
\text { CA- lymphocyte } \\
\text { SCE- lymphocyte }\end{array}$ & $\begin{array}{l}\text { MN-lymphocyte- } \\
\uparrow^{*} \\
\text { CA- } \uparrow^{*} \\
\text { SCE- } \uparrow^{*}\end{array}$ & 2.93 & $10 / 27$ & $\begin{array}{l}\text { Fučic et al. } \\
\text { [32] }\end{array}$ \\
\hline $\begin{array}{l}\text { Hospital workers, } \\
\text { Brazil }\end{array}$ & 2000 & $\begin{array}{l}\text { E: } 10 \mathrm{~m}(35.8 \pm 6.5) \\
\text { C: } 10 \mathrm{~m}(35.9 \pm 7.8)\end{array}$ & NR & NR & $\begin{array}{l}\text { MN-lymphocyte- MN scored in } \\
2000 \text { binucleated cells }\end{array}$ & $\begin{array}{l}\text { MN-lymphocyte- } \\
\leftrightarrow \\
\text { CA- } \uparrow^{*}\end{array}$ & 0.82 & $15 / 27$ & $\begin{array}{l}\text { Maluf and } \\
\text { Erdtmann } \\
{[33]}\end{array}$ \\
\hline $\begin{array}{l}\text { Hospital workers, } \\
\text { South Korea }\end{array}$ & 2011 & $\begin{array}{l}\text { E: } 35(40.1 \pm 9.7) \\
\text { C: } 62(40.1 \pm 9.7)\end{array}$ & $\begin{array}{l}\text { E: } 0.010 \mathrm{ppm} \\
\text { C: } 0.001 \mathrm{ppm}\end{array}$ & \# & $\begin{array}{l}\text { MN-lymphocyte } \\
\text { scored in binucleated cells }\end{array}$ & MN-lymphocyte- & Not calculated & $\begin{array}{l}\text { QS not } \\
\text { calculated }^{\#}\end{array}$ & $\begin{array}{l}\text { Lee et al. } \\
{[35]^{\#}}\end{array}$ \\
\hline
\end{tabular}

$\rightarrow$ Unaltered; $\uparrow$ Increase; $\downarrow$ Decrease; * significant; ${ }^{\mathrm{t}}$ : Groups as defined by authors.

${ }^{\#}$ Study published in Korean, hence data presented here are based on limited understanding of the paper, and therefore QS has not been calculated.

$\mathrm{m}$-Male; f-Female; E-Exposed; C-Control; $8 \mathrm{~h}$ TWA-8 $\mathrm{h}$ time weighted average; NR-not reported

QS-Quality score; ^FR-Frequency ration calculated as $\mathrm{MN}$ in exposed population/MN in control, calculated only for MN scored in lymphocytes, significant values represented in bold

MN-micronucleus; PC-polychromatic erythrocyte; CA-Chromosomal aberration; SCE-Sister Chromatid Exchange; EtO-Hb- EtO-Haemoglobin adducts; Hb-Haemoglobin 


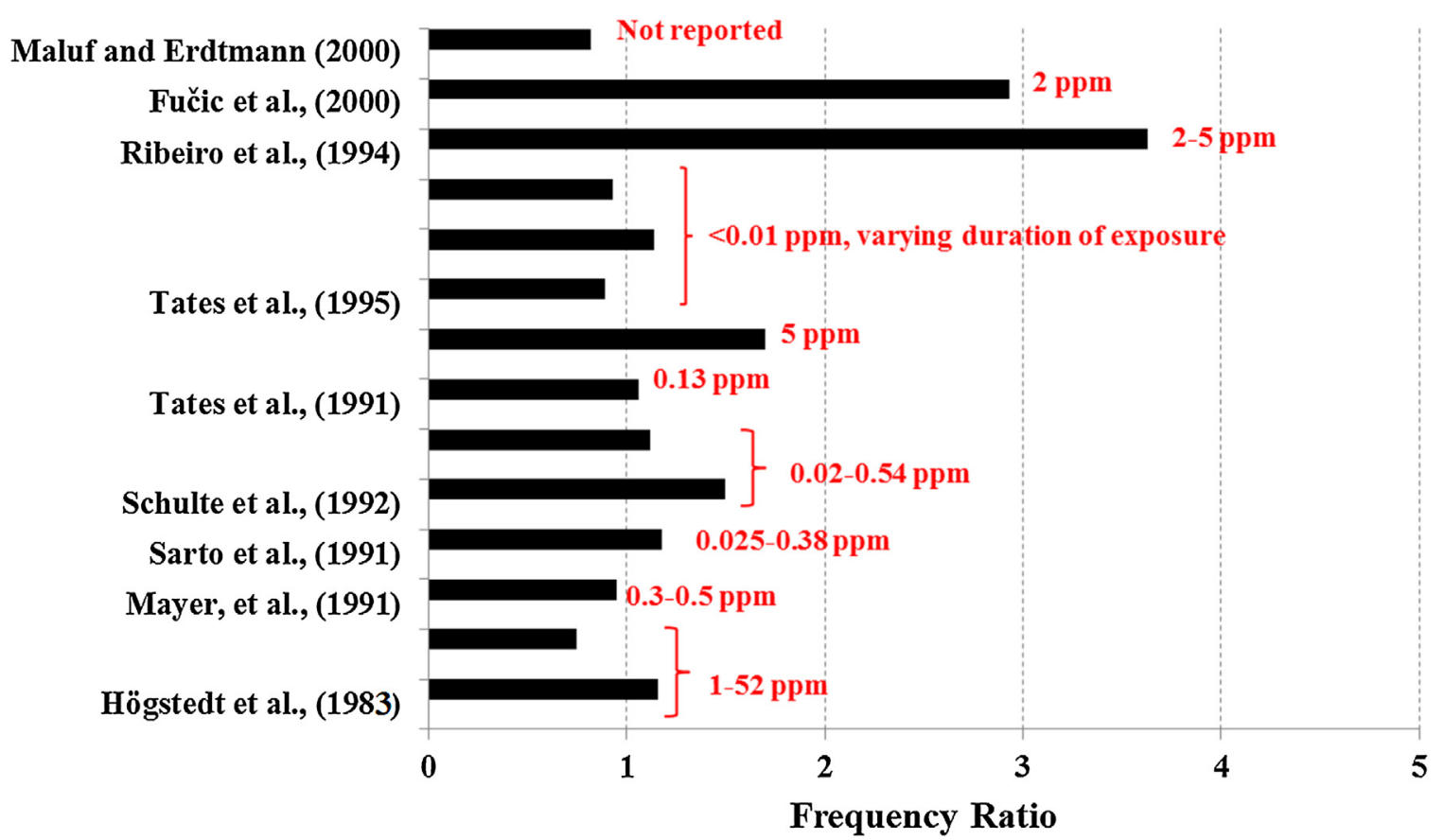

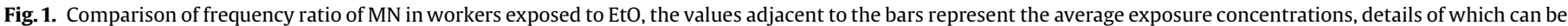
found in Table 1.

workers and control $(\mathrm{FR}=0.95)$. The study results suggest a poor correlation between MN formation and EtO exposure in general and EtO-Hb adduct formation in particular. The authors suggested that SCEs might be more sensitive to EtO exposure than MN and CA.

Sarto et al. [26], studied 10 sterilization workers, to understand the effect of EtO exposure on adduct formation and different cytogenetic parameters. The study included a control group of 10 unexposed nurses from the same hospital. The mean exposure to EtO was $0.025-0.38 \mathrm{ppm}$. Among the 10 workers, 3 were subjected to an accidental exposure to EtO, but for a very short duration. EtO$\mathrm{Hb}$ concentrations were measured to describe the exposure. The exposed group (78-430 $\mathrm{pmol} / \mathrm{mg} \mathrm{Hb}$ ) had a significantly higher amount of adducts, compared to the control (21-88 pmol/ $\mathrm{mg} \mathrm{Hb}$ ). SCE and MN were performed to understand the cytogenetic effect of EtO exposure. The mean SCE frequency in the exposed workers was not statistically different from the control. MN formation were studied in lymphocyte cells, however no significant difference was observed between exposure and control groups ( $F R=1.18$ ). Similar observations were made for MN formation in buccal cells.

Sarto et al. [9] reported in another publication the effect of EtO exposure on exfoliated cells of the nose and mouth. MN was studied in a group of 9 subjects working in sterilization unit, exposed to $8 \mathrm{~h}$-TWA concentration $<0.38 \mathrm{ppm}$. Additionally, the study reported also data of an accidental exposure to higher levels of EtO in 3 of the workers. The frequency of MN in buccal mucosa remained unaltered as previously reported by the group. In contrast, the MN frequency in nasal mucosa was altered in 2 of the subjects, accidentally exposed to higher concentrations of EtO. The chronic exposure did not alter the MN frequency.

In a later study by Schulte et al. [27], similar association between SCE, MN and EtO-Hb were observed. Schulte et al. [27] studied a total of 73 workers, mostly female ( $\sim 96 \%)$ from nine hospitals in the USA and one hospital in Mexico City. EtO exposure was monitored over a period of 4 months before the sampling. The $8 \mathrm{~h}$ TWA exposure to EtO was determined to be between $0.02 \mathrm{ppm}$ and $0.54 \mathrm{ppm}$. Based on the EtO exposure the subjects were grouped as not exposed ( $0 \mathrm{ppm} 8 \mathrm{~h}$-TWA), low exposure (0.02$0.30 \mathrm{ppm} 8 \mathrm{~h}$-TWA) and high exposure (0.13-1.36 ppm $8 \mathrm{~h}$-TWA). A strong association between EtO exposure, EtO-Hb adduct and SCE formation were observed by the authors. The MN formation was studied using the method of Hogstedt et al. [24] in lymphocytes and a minimum of 1000 cells were scored for the analysis. No significant changes in MN frequency (expressed as frequency/cell) were observed in the American population, between the nonexposed $(0.51 \mathrm{ppm})$, low exposure $(0.48 \mathrm{ppm})$ and high exposure groups $(1.06 \mathrm{ppm})(\mathrm{FR}=1.51)$. Similar results were observed for the Mexican population as well $(\mathrm{FR}=1.12)$.

A study by Tates et al. [28] investigated the effect of EtO in German workers involved in Sterilization of medical equipment. The group of workers (EI: $22-72 \mathrm{ppm}$ and EII: 14 and $28 \mathrm{ppm}$; occasional peak exposure 400-700 ppm) was matched for age, sex and smoking habits with the control groups (Control: $\mathrm{CI}$ and $\mathrm{CII}$ ). The values of EtO-Hb adduct were significantly higher in the exposed group (E I: 0.179 nmol/g Hb; E II: 7.70 pmol/rng Hb) when compared to their respective controls (C I: $0.066 \mathrm{pmol} / \mathrm{g} \mathrm{Hb}$; C II: $0.102 \mathrm{pmol} / \mathrm{g} \mathrm{Hb}$ ). In addition to exposure measurement, all samples were analyzed for HPRT mutants (MFs), SCEs, CA and MN. While SCE and CA were significantly higher, MF for exposed group was unaltered. Unlike in the previous studies, in the present study MN were studied in binucleated cells according to the method of Fenech and Morley [29]. The results suggested no significant change in MN frequency between $\mathrm{E} I$ and $C \mathrm{I}(\mathrm{FR}=1.06)$. However, the number of MN in higher exposure group E II was significantly higher compared to C II $(F R=1.70)$. The relative sensitivity of endpoints studied was suggested to be in the following order: EtO-Hb adducts $>$ SCEs $>$ CA $>$ MN $>$ HPRT mutants.

A later study by Tates et al.[30] considered four exposure groups to understand the effect of incidental and chronic low dose exposure. The groups were well defined based on the number of subjects, concentration and duration of exposure, smoking habits (Table 1, EI-E IV). EtO-Hb adduct reflected the concentration and 
duration of exposure in each of the four groups. No significant change in HPRT mutation and SCE were observed. Whole blood culture was established to study the formation of MN in 10001500 binucleated lymphocyte cells. The number of MN/1000 cells in all the groups were between 15 and 16 (FR=EI: EIV-0.89; EII: EIV-1.14; EIII: EIV-0.93). The authors provided for a possible explanation, that since the sampling was 3 months after the incidental exposure, the damages could have been repaired and hence were not detected in the assays. They also inferred that the mutagenic/cytogenetic changes induced by EtO were not permanent.

In another important study Ribeiro et al. [31] investigated the effect of EtO in exposed works $(n=75)$ from Brazil. The study included 22 control subjects. EtO concentrations in ambient air were measured over a period of 3 months. The workers were exposed to an $8 \mathrm{~h}$-TWA concentration of $2-5 \mathrm{ppm}$ EtO. EtO-Hb adduct in the exposed group $(294 \pm 121 \mathrm{nmol} / \mathrm{g} \mathrm{Hb})$ were significantly higher compared to the control population $(92 \pm 78$ $\mathrm{nmol} / \mathrm{g} \mathrm{Hb}$ ). However the results are limited by fact that it was measure only in 8 workers and 5 controls. Results of CA indicated a significant increase in aberration in the exposed group compared to the control. Cytokinesis-blocked MN (CBMN) assay was performed in lymphocytes. However, MN was performed only in 16 workers and 11 control samples. Thousand binucleated cells were scored for the assay. A significant increase in the number of $\mathrm{MN}$ were observed in exposed workers (FR =3.6). Additionally MN was studied in exfoliated epithelial cells; however exposure to EtO did not affect the MN frequency $(F R=1.18)$. Rapid renewal and alternative route of EtO exposure were put forward as explanation for the absence of MN in exfoliated cells.

Fučic et al. [32], conducted a pilot study with 11 exposed and 20 control female subjects working in a Croatian hospital. The average exposure during sterilization process was reported to be $2 \mathrm{ppm}$. Cytogenetic endpoints like SCE, CA and MN were studied in lymphocyte cells. A significant increase in SCE frequency was observed in the exposed population. Higher numbers of chromosome breaks were observed in the exposed group (5.5) as compared to the control (0.7). MN assay was performed in lymphocyte cells according to the method of Fenech and Morley [29]. A significant increase in MN formation was observed in the exposed workers.

A study by Maluf and Erdtmann [33] investigated 10 subjects (male, $35.8 \pm 6.5$ ) from a Brazilian hospital, occupationally exposed to EtO. The control group comprised of ten age and sex matched (male, $35.9 \pm 7.8$ ) population. The authors performed MN assay according to the methods of Fenech [34]. The presence of MN were determined in 2000 binucleated cells per individual, however no significant alterations were observed ( $F R=0.82$ ).

Lee et al. [35] investigated the role of GSTM1, GSTT1, XRCC1, and XRCC3 polymorphism and genotoxicity in an epidemiological setup. However, this article published in the Korean Journal of Environmental Health Sciences [35] is in Korean, which limits our understanding of the manuscript. The results could only be discussed to a limited extent based on the abstracts, tables and figures. The study population comprised of 35 occupationally exposed workers, and 62 controls. The average age of the control group was $31.6 \pm 12.5$ years, while that of the exposed group was $40.1 \pm 9.7$ years. The frequencies of micronuclei (CBMN assay) in EtO exposure group were significant higher, compared to the control group. A dose-response between MN frequency EtO exposure was observed but was not statistically significant. The authors investigated the role of GSTM1, GSTT1, XRCC1, and XRCC3 polymorphism on MN frequency but no association was observed. The findings by Lee et al. [35] were consistent with that reported by Godderis et al. [36]. However, the EtO concentration for exposed population $(0.010 \mathrm{ppm})$ and control $(0.001 \mathrm{ppm})$, were not significantly different as in most other studies which could possibly explain the lack of difference between the group.

\section{Discussion}

Based on animal studies and epidemiological evidences, EtO has been categorized as "carcinogenic to humans (Group 1)" by IARC. However, the findings from human studies are often inconsistent and inconclusive as highlighted by the IARC Monograph [4-6]. A limited number of study have reported the mortality and cancer incidence in workers exposed to EtO [17-19,37-40], while some have reported otherwise [40-43]. In addition to carcinogenicity studies, significant information regarding toxicity of EtO in human population has been obtained from results of haemoglobin adduct formation, chromosomal aberrations (CA), sister chromatid exchange (SCE), micronucleus assay (MN) among others. For the interest of the present review, we discuss the results obtained from micronucleus assay in human lymphocyte cells, highlighting the lacunae. The review has been based on a limited number of $(n=11)$ papers, shortlisted by authors based on their inclusion of MN assay. Interestingly most of the studies discussed were published between 1985 and 2000, before EtO was classified as "known to be a human carcinogen" in the Ninth Report on Carcinogens in 2000 [21].

It would be important to understand that from the limited number of studies discussed in the review, it is difficult to make a general conclusion regarding micronucleus assay. While $\mathrm{MN}$ has been studied in lymphocyte cells, quantitative evaluations of the data with respect to exposure could not be performed due to uncertainties in the concentration and duration of exposure, time points selected and small size of the population. In addition, some of these studies lack proper description of the method used and subsequent scoring of micronucleus. In this section the different points affecting the sensitivity and assay outcome have been discussed in brief.

While all of the discussed studies scored MN in lymphocyte cells, the cell type chosen to initiate cell culture varied significantly. While many of these studies have used whole blood to initiate culture [28,30], others have used isolated lymphocyte for the assay. The time used for cell culture also varied considerably from one study to the other. Mayer et al. [25], harvested cells after 64-66 h of culture to study MN, while Schulte et al.[27], harvested cells at 84 and $96 \mathrm{~h}$. Tates et al. [28,30], in their study used a total culture time of $72 \mathrm{~h}$, with Cytochalasin B added after the $44 \mathrm{~h}$. However the most important aspect that makes these studies incomparable is the form of MN assay used. In some of the studies MN were evaluated in mononuclear cells $[23,25,27]$, while in others the CBMN assay was used.

For a better understanding of the results discussed, with respect to EtO $8 \mathrm{~h}$-TWA exposure, the results of the different MN assays (in mononucleate and binucleated cells) were compared independently. The mean $\mathrm{MN}$ frequencies ( $\mathrm{FR}=0.75-3.63)$ obtained from these studies were compared to the EtO exposure concentrations. A poor correlation between $\mathrm{MN}$ formation and EtO exposure concentrations (CBMN, $R=0.154$; $\mathrm{MN}$ in mononucleate cells, $R=0.132$ ) were observed from these studies. It might be important to mention here, that positive results of MN were observed in only three of the studies reported [28,31,32], where the EtO exposure concentrations were much higher (2-28 ppm $8 \mathrm{~h}$-TWA) than the present recommended levels ( $<1 \mathrm{ppm})$. At the concentration lower than $1 \mathrm{ppm}$, MN formation was not observed [23,25-31,30,33] irrespective of the form of MN assay used.

Additionally, it can be pointed out that sample size plays an important role in the sensitivity of MN assays in the discussed studies. By calculating the mean difference $(=0.62)$ between control and exposed population $(R=0.148)$, a required sample size 
of $n=270$ with approximate $80 \%$ power (alpha $=0.05$, two-sided) was obtained. This value is much higher than that reported in any of these studies ( $n=7-75)$. A power calculation based on the above studies might be reflective of the sensitivity of MN assays. However, a calculation would be more appropriate based on age and gender matched pilot study, which would allow establishing background values of $\mathrm{MN}$ formation in the population at a more realistic exposure scenario.

These studies additionally provided some insight regarding the choice of cells and their influence on the micronucleus assay. Högstedt et al. [22] in their study indicated that MN assay in bone marrow cells was a better indicator than lymphocyte MN. In some of the other studies MN formation was evaluated in exfoliated buccal and nasal cells, in addition to lymphocyte cells. In the study by Sarto et al. [26] the MN frequency in both buccal and lymphocyte cells remained unaltered by the EtO exposure. Sarto et al. [9], in another publication, reported higher MN frequency in nasal mucosa in 2 subjects accidentally exposed to higher concentrations of EtO. While Ribeiro et al. [31], reported a 3.5 fold increase in the number of MN in lymphocyte cells, however no such effect were observed in the exfoliated cells. Given the difference in sensitivity of different cell types observed from the limited number of studies, it would be interesting to compare the effect of EtO exposure on MN formation in exfoliated buccal and nasal cells (source of exposure), lymphocyte (circulatory system), and urothelial cells (excretion of metabolites).

The results of the studies additionally reveal that $\mathrm{MN}$ is relatively less sensitive towards EtO exposure, when compared to other cytogenetic endpoints like SCE and CA. In the studies [25-28] where SCE, CA and MN were performed simultaneously, SCE was found to be most sensitive, followed by $\mathrm{CA}$ and $\mathrm{MN}$ respectively. The levels of EtO and EtO-Hb adducts in all the studies were strongly correlated to the results of SCE and not MN.

\section{Conclusion and recommendation}

From the studies discussed in the present review, interpretation of results based on the MN assay has been limited by the lack of a harmonized protocol, use of proper cell culture/harvesting conditions and scoring criteria. Moreover the positive results have often been reported at a much higher concentrations (2-30 ppm), and in a very small number of subjects (often $n=<10$ ). From the limited number of studies available, it is extremely difficult to determine sensitivity or understand dose response of MN assay towards EtO exposure. To clearly understand the effect of exposure of EtO on MN assay outcome, the following lacunae should be addressed:

i. Use of a harmonized protocol for exposure assessment and MN assay (CBMN cytome assay)

ii. Studies should be designed based on power calculation to determine suitable samples size

iii. Use of multiple target tissues, to determine sensitivity of MN for EtO bio-monitoring studies.

\section{Conflict of interest}

None.

\section{Appendix A. Supplementary data}

Supplementary data associated with this article can be found, in the online version, at http://dx.doi.org/10.1016/j. mrrev.2016.05.002.

\section{References}

[1] CAREX, Carex: Industry Specific Estimates Occupational Exposure to Chemical Agents in Finland, (1999) . (accessed May, 2016) http://www.ttl.fi/en/ chemical_safety/carex/countries/pages/default.aspx.

[2] NIOSH, National Occupational Exposure Survey, Ethylene Oxide, (1981-1983). (accessed May, 2016) http://www.cdc.gov/noes/noes1/32550sic.html.

[3] CAREX-Canada, http://www.carexcanada.ca/en/ethylene_oxide/ \#occupational_exposures; (accessed May, 2016).

[4] IARC (2012). Ethylene oxide. IARC Monograph 100F: 379-400.

[5] IARC, Some industrial chemicals, IARC Monogr. Eval. Carcinog. Risks Hum. 60 (1994) 1-560.

[6] IARC, 1,3-Butadiene, ethylene oxide and vinyl halides vinyl fluoride, vinyl chloride and vinyl bromide, IARC Monogr. Eval. Carcinog. Risks Hum. 97 (2008) $1-510$.

[7] D. Deschamps, N. Rosenberg, P. Soler, G. Maillard, E. Fournier, D. Salson, P. Gervais, Persistent asthma after accidental exposure to ethylene oxide, Br. J. Ind. Med. 49 (7) (1992) 523.

[8] M. Bader, W. Will, G. Frey, M. Nasterlack, Analysis of protein adducts as biomarkers of short-term exposure to ethylene oxide and results of follow-up biomonitoring, Arhiv. Za Higijenu Rada I Toksikologiju 63 (2) (2012) 107.

[9] F. Sarto, R. Tomanin, L. Giacomelli, G. Iannini, A.R. Cupiraggi, The micronucleus assay in human exfoliated cells of the nose and mouth: application to occupational exposures to chromic acid and ethylene oxide? Mutat. Res. Lett. 244 (4) (1990) 345-351.

[10] W.E. Luttrell, Ethylene oxide, J. Chem. Health Saf. 15 (6) (2008) 30-32.

[11] W.J. Estrin, R.M. Bowler, A. Lash, C.E. Becker, Neurotoxicological evaluation of hospital sterilizer workers exposed to ethylene oxide? J. Toxicol.: Clin. Toxicol. 28 (1) (1990) 1-20.

[12] A. Brashear, F.W. Unverzagt, M.O. Farber, J.M. Bonnin, J.G.N. Garcia, E. Grober, Ethylene oxide neurotoxicity A cluster of 12 nurses with peripheral and central nervous system toxicity? Neurology 46 (4) (1996) 992-998.

[13] F. Li, A. Segal, J.J. Solomon, In vitro reaction of ethylene oxide with DNA and characterization of DNA adducts, Chem.-Biol. Interact. 83 (1) (1992) 35-54.

[14] J.A. Swenberg, A. Ham, H. Koc, E. Morinello, A. Ranasinghe, N. Tretyakova, K.Y. Wu, DNA adducts: effects of low exposure to ethylene oxide, vinyl chloride and butadiene, Mutat. Res.Genet. Toxicol. Environ. Mutagen. 464 (1) (2000) 77-86.

[15] J.G. Filser, B. Denk, M. Törnqvist, W. Kessler, L. Ehrenberg, Pharmacokinetics of ethylene in man; body burden with ethylene oxide and hydroxyethylation of hemoglobin due to endogenous and environmental ethylene? Arch. Toxicol. 66 (3) (1992) 157-163.

[16] T. Schettgen, H.C. Broding, J. Angerer, H. Drexler, Hemoglobin adducts of ethylene oxide propylene oxide, acrylonitrile and acrylamide-biomarkers in occupational and environmental medicine, Toxicol. Lett. 134 (1) (2002) 65-70.

[17] C. Hogstedt, L. Aringer, A. Gustavsson, Epidemiologic support for ethylene oxide as a cancer-causing agent? JAMA 255 (12) (1986) 1575-1578.

[18] L. Hagmar, Z. Mikoczy, H. Welinder, Cancer incidence in Swedish sterilant workers exposed to ethylene oxide, Occup. Environ. Med. 52 (3) (1995) 154 156.

[19] K. Steenland, E. Whelan, J. Deddens, L. Stayner, E. Ward, Ethylene oxide and breast cancer incidence in a cohort study of 7576 women (United States), Cancer Causes Control 14 (6) (2003) 531-539.

[20] Z. Mikoczy, H. Tinnerberg, J. Björk, M. Albin, Cancer incidence and mortality in Swedish sterilant workers exposed to ethylene oxide: updated cohort study findings 1972-2006? Int. J. Environ. Res. Public Health 8 (6) (2011) 2009-2019.

[21] NTP (National Toxicology Program), Report on Carcinogens, thirteenth edition, U.S. Department of Health and Human Services, Public Health, Research Triangle Park, NC, 2014

[22] B. Högstedt, B.O. Gullberg, K. Hedner, A. Kolnig, F. Mitelman, S. Skerfving, B. Widegren, Chromosome aberrations and micronuclei in bone marrow cells and peripheral blood lymphocytes in humans exposed to ethylene oxide? Hereditas 98 (1) (1983) 105-113.

[23] B. Högstedt, E. Bergmark, M. Törnqvist, S. Osterman golkar, Chromosomal aberrations and micronuclei in lymphocytes in relation to alkylation of hemoglobin in workers exposed to ethylene oxide and propylene oxide, Hereditas 113 (2) (1990) 133-138.

[24] B. Högstedt, Micronuclei in lymphocytes with preserved cytoplasm: a method for assessment of cytogenetic damage in man? Mutat. Res./Environ. Mutagen Relat. Subj. 130 (1) (1984) 63-72.

[25] J. Mayer, D. Warburton, A.M. Jeffrey, R. Pero, S. Walles, L. Andrews, et al., Biologic markers in ethylene oxide-exposed workers and controls, Mutat. Res./ Fundam. Mol. Mech. Mutagen. 248 (1) (1991) 163-176.

[26] F. Sarto, M.Å. Törnqvist, R. Tomanin, G.B. Bartolucci, S.M. Osterman-Golkar, L. Ehrenberg, Studies of biological and chemical monitoring of low-level exposure to ethylene oxide, Scand. J. Work Environ. Health (1991) 60-64.

[27] P.A. Schulte, M. Boeniger, J.T. Walker, S.E. Schober, M.A. Pereira, D.K. Gulati, et al., Biologic markers in hospital workers exposed to low levels of ethylene oxide, Mutat. Res./Genet. Toxicol. 278 (4) (1992) 237-251.

[28] A.D. Tates, T. Grummt, M. Törnqvist, P.B. Farmer, F.J. Van Dam, H. Van Mossel, et al., Biological and chemical monitoring of occupational exposure to ethylene oxide, Mutat. Res./ Fundam. Mol. Mech. Mutagen. 250 (1) (1991) 483-497.

[29] M. Fenech, A.A. Morley, Measurement of micronuclei in lymphocytes, Mutat Res. 147 (1985) 29-36. 
[30] A.D. Tates, P.J. Boogaard, F. Darroudi, A.T. Natarajan, M.E. Caubo, N.J. Van Sittert, Biological effect monitoring in industrial workers following incidental exposure to high concentrations of ethylene oxide? Mutat. Res./Fundam. Mol. Mech. Mutag. 329 (1) (1995) 63-77.

[31] L.R. Ribeiro, D.M.F. Salvadori, A.C.C. Rios, S.L. Costa, A.D. Tates, M. Törnqvist, A.T. Natarajan, Biological monitoring of workers occupationally exposed to ethylene oxide? Mutat. Res./Environ. Mutagen. Relat. Subj. 313 (1) (1994) 81 87.

[32] A. Fučic, R. Rozgaj, A. Jazbec, A. Mijić, Genotoxic consequences of occupational exposure to ethylene oxide and formaldehyde-a pilot study? Toxicol. Environ. Chem. 75 (1-2) (2000) 59-66.

[33] S.W. Maluf, B. Erdtmann, Evaluation of occupational genotoxic risk in a Brazilian hospital, Genet. Mol. Biol. 23 (2) (2000) 485-488.

[34] M. Fenech, The cytokinesis-block micronucleus technique: a detailed description of the method and its application to genotoxicity studies in human populations? Mutat. Res./Fundam. Mol. Mech. Mutagen. 285 (1) (1993) 35-44.

[35] S.Y. Lee, Y.J. Kim, Y.J. Choi, J.W. Lee, Y.H. Lee, M.Y. Shin, H.W. Chung, Analysis of micronuclei and its association with genetic polymorphisms in hospital workers exposed to ethylene oxide, Korean J. Environ. Health Sci. 37 (6) (2011) 429-439.

[36] L. Godderis, P. Aka, R. Mateuca, M. Kirsch-Volders, D. Lison, H. Veulemans, Dose-dependent influence of genetic polymorphisms on DNA damage induced by styrene oxide: ethylene oxide and gamma-radiation, Toxicology 219 (1) (2006) 220-229.

[37] C. Hogstedt, O. Rohlen, B.S. Berndtsson, O. Axelson, L. Ehrenberg, A cohort study of mortality and cancer incidence in ethylene oxide production workers, Br. J. Ind. Med. 36 (4) (1979) 276-280.

[38] C. Hogstedt, N. Malmqvist, B. Wadman, Leukemia in workers exposed to ethylene oxide, JAMA 241 (11) (1979) 1132-1133.

[39] K. Steenland, L. Stayner, A. Greife, W. Halperin, R. Hayes, R. Hornung, S. Nowlin, Mortality among workers exposed to ethylene oxide? N. Engl. J. Med. 324 (20) (1991) 1402-1407.

[40] Z. Mikoczy, H. Tinnerberg, J. Björk, M. Albin, Cancer incidence and mortality in Swedish sterilant workers exposed to ethylene oxide: updated cohort study findings 1972-2006, Int. J. Environ. Res. Public Health 8 (6) (2011) 2009-2019.

[41] M.J. Gardner, D. Coggon, B. Pannett, E.C. Harris, Workers exposed to ethylene oxide: a follow up study, Br. J. Ind. Med. 46 (12) (1989) 860-865.

[42] M.J. Teta, R.L. Sielken, C. Valdez-Flores, Ethylene oxide cancer risk assessment based on epidemiological data: application of revised regulatory guidelines, Risk Anal. 19 (6) (1999) 1135-1155.

[43] D. Coggon, E.C. Harris, J. Poole, K.T. Palmer, Mortality of workers exposed to ethylene oxide: extended follow up of a British cohort, Occup. Environ. Med. 61 (4) (2004) 358-362. 